Instructions for authors, subscriptions and further details: http://rasp.hipatiapress.com

\title{
Senior Citizens during COVID-19 Crisis in the Philippines: Enabling Laws, Current Issues, and Shared Efforts.
}

Michael Cahapay

College of Education, Mindanao State University, General Santos City

Date of publication: January $30^{\text {th }}, 2021$

Edition period: January 2021 - July 2021

To cite this article: Cahapay, M. (2021). Senior Citizens during COVID-19 Crisis in the Philippines: Enabling Laws, Current Issues, and Shared Efforts. Research on Ageing and Social Policy, 9(1), 1-25. http://10.4471/rasp.2021.6066

To link this article: http://dx.doi.org/10.447/rasp.2021.6066

\section{PLEASE SCROLL DOWN FOR ARTICLE}

The terms and conditions of use are related to the Open Journal System and to Creative Commons Attribution License (CCAL). 


\section{Senior Citizens during COVID-19 Crisis in the Philippines: Enabling Laws, Current Issues, and Shared Efforts}

Michael Cahapay

Mindanao State University

(Received: 30 june 2020; Accepted: 18 july 2021; Published: 30 January 2021)

\section{Abstract}

While the COVID-19 crisis has affected people of all walks, there is an unheard side of the vulnerable aged group across the globe. This article discusses the condition of senior citizens in the Philippines during the COVID-19 crisis. The review showed that various enabling laws through the constitution, republic acts, and executive orders, have been enacted to secure the welfare of senior citizens. However, the current crisis has revealed ageism issues such as deprivation of income sources, inaccessibility to essential needs, inadequate physical space, and spoken negative perceptions. Shared efforts have been focused to improve social pension payout, guidelines for mobility, different approaches of remote access to goods and services, and meaningful internet connectivity within the context of the senior citizens. This paper suggests the need to translate the laws into effective programs, discuss related ageism issues with sensitivity, and consider evidence of successful international efforts to further improve the condition of the senior citizens in the country.

Keywords: senior citizens, social policy, COVID-19, Philippines

2021 Hipatia Press

ISSN: 2014-6728

DOI: $10.447 /$ rasp.2021.6066 


\section{Ciudadanos de la Tercera Edad durante la Crisis de COVID-19 en Filipinas: Leyes Favorables, Problemas Actuales y Esfuerzos Compartidos}

Michael Cahapay

Mindanao State University

(Recibido: 30 Junio 2020; Aceptado: 18 Julio 2021; Publicado: 30 Enero 2021)

\section{Resumen}

Si bien COVID-19 afecta a todas las edades, existe un lado desconocido de un grupo vulnerable de personas mayores en todo el mundo en medio de la crisis actual. Este artículo analiza la condición de las personas mayores en Filipinas durante la crisis de COVID-19. La revisión mostró que se han promulgado varias leyes habilitantes para garantizar el bienestar de las personas mayores. Sin embargo, la crisis actual reveló problemas como la privación de las fuentes de ingresos, la inaccesibilidad a las necesidades esenciales, el espacio físico inadecuado y las percepciones negativas no expresadas, que afectan en gran medida a las personas mayores. Por lo tanto, para implementar las leyes y resolver los problemas, los esfuerzos compartidos deberían centrarse en mejorar el pago de las pensiones sociales, las pautas para la movilidad, los diferentes enfoques de acceso remoto a bienes y servicios esenciales y la conectividad a Internet significativa en el contexto de las personas mayores

Keywords: senior citizens, social policy, COVID-19, Philippines

2021 Hipatia Press

ISSN: 2014-6728

DOI: $10.447 /$ rasp.2020.6066 


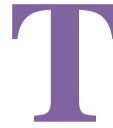
he global outbreak of COVID-19 has affected people of all walks and especially the segment of older people. Early evidence from China, where the disease is believed to have originated, indicates that a majority of mortality caused by COVID-19 occur among older people aged 60 years above (Lai, Shih, Ko, Tang, $\&$ Hsueh, 2020). The case of Europe, which later became one of the epicenters of COVID-19, reported a greater majority of fatalities for people 60 years old and above (World Health Organization, 2020).

This vulnerability of older people to COVID-19 is further exacerbated by anecdotal indications of ageism transpiring at different levels. Ageism occurs at the structural level in which institutions otherwise support societal prejudice against elderly people and individual level in which elderly people absorb the unfavorable cultural opinions about aging (Chang, Kannoth, Levy, Wang, Lee, \& Levy, 2020). It can be observed in recent scholarly reports that such ageism occurring at different levels has never been magnified as large as its case in the current COVID-19 situation (Banerjee, 2020; Reynolds, 2020).

As a response, the United Nations (2020) has laid down four key priorities for action to safeguard the overall welfare of the older people during the COVID-19 crisis. It encouraged stakeholders to ensure that challenging decisions related to health care for older people are well guided, strengthen the social inclusion of older people in preventive measures, integrate an emphasis on older people into the different humanitarian responses, and enjoin the participation of older people in developing policies that affect them. As a ripple effect, different member states have taken measures to curb the impacts of the present global outbreak on older people by considering these key priorities for action.

The older people in the Philippines are called "senior citizens," defined in the Republic Act No. 7432 as any resident citizen of this country with at least 60 years of age. The Philippines, by age structure, can be considered as a young society in which only less than 10 percent of the population are senior citizens. As of the 2015 
census, the Philippine Statistics Authority reported that 7.5 million are senior citizens, accounting for only 7.5 percent of the total national population. Despite the reports of some major gaps in the health status of Filipino senior citizens, there is also a trend that indicates improving functional health and increasing life expectancy among Filipino senior citizens (Cruz, 2019; Fabon, 2019).

The rights of Filipino senior citizens are enshrined in the different Philippine laws which protect them in difficult times such as the present COVID-19 crisis. The care policies that serve to manage the older people during this difficult period have been highlighted in the context of developed countries and territories (e.g. see Béland \& Marier, 2020 in Canada; Lum, Shi, Wong \& Wong, 2020) in Hong Kong). On this note, it is likewise interesting to review the laws that serve as drivers to safeguard the welfare of senior citizens especially considering the current situation in a developing country like the Philippines.

The COVID-19 crisis has also raised ageism issues worsening the situation of Filipino senior citizens (Paul, 2020) and with a gender dimension within this aged population (Cruz, Cruz, \& Saito, 2018). These issues are elaborated in the recent studies that reveal ageism and the different social, economic, psychological, and physical vulnerabilities faced by the older people (Banerjee, 2020; De Leo \& Trabucchi, 2020; Deusdad, 2020; Ghilarducci \& Farmand, 2020; Liotta, Marazzi, Orlando, \& Palombi, 2020; Meng, Xu, Dai, Zhang, Liu, \& Yang, 2020). These studies are significant as they open notions in the current paper to explore the related issues affecting the senior citizens in the context of the Philippines.

Furthermore, Ducanes, Daway-Ducanes, \& Ravago (2020) called for a need to exert efforts to assist Filipino senior citizens during the COVID-19 crisis. A closer look at scholarly reports (Angel \& Mudrazija, 2020; Hoffman, Webster, \& Bynum, 2020; MorrowHowell, Galucia, \& Swinford, 2020; Previtali et al., 2020; Xie et al., 2020) show that various good practices to meet the integral needs of the older people during this time have been placed. Thus, it is a timely 
opportunity to discuss, as well as learn from the above scholarly reports, what efforts are presently offered to improve the quality of life of senior citizens, especially in the Philippines.

Drawing perspectives from the current crisis and relevant scholarly works, the current paper is grounded on the importance of safeguarding the welfare of older people. There have also been calls in the research communities to discuss the condition of older people during the current crisis. Thus, this paper intended to discuss the condition of the senior citizens in the Philippines during the COVID19 crisis by reviewing the enabling laws, current issues, and shared efforts.

\section{Method}

\section{Research Design}

The present article is carried out as a desk review. A desk review is defined as a type of research that involves the collection of relevant data from various sources (Sileyew, 2019) which may include legal codes, historical records, statistical data, published papers, news articles, review articles, and other pieces that have a descriptive or analytical purpose (Guptill, 2016).

This research design is appropriately employed in this paper to provide structured search, collection, and analysis of the different enabling laws, current issues, and shared efforts that affect the current condition of the senior citizens during COVID-19 in the Philippines.

\section{Research Context}

This research is situated within the context of Filipino senior citizens or residents with an age of at least 60 years old. The Philippines is a country which, by age population, can be considered as a young society with a proportion of senior citizens below 10 percent of the total population (Cruz, 2019). 
Furthermore, this research is discussed within the global context of the current COVID-19 crisis. This global crisis has put attention on the deleterious impacts of engrained ageism and other issues related to vulnerable groups of the society (Morrow-Howell et al., 2020).

\section{Data Sources}

The data sources for this paper can be considered as primary sources and secondary sources. These primary sources and secondary sources were selected based on the following five inclusion criteria: written in intelligible language, accessible in full text, authored by credible persons or institutions, focused on the enabling laws, current issues, and shared efforts, and relevant to the condition of the senior citizens during the COVID-19 period in the Philippines.

The primary sources are original documents, data, or images (Guptill, 2016). These primary sources in this paper mainly consist of government documents such as the 1987 Philippine Constitution, various republic acts, and executive orders. On the other hand, the secondary sources are referred to as sources that are produced through the analysis of primary sources (Guptill, 2016). Since this study is interested in the continuous record of particular activities related to senior citizens at some points, the secondary sources in this paper largely consist of policy briefs published by national institutions, news articles produced by various local media outlets, and other relevant written materials accessed online.

\section{Data Analysis}

The documents searched were analyzed through a technique called document analysis. It is a technique that "requires repeated review, examination, and interpretation of the data in order to gain empirical knowledge of the construct being studied" (Frey, 2018). Furthermore, the analysis of documents involves the examination of the codes into themes comparable to how interview transcripts are processed 
(Bowen, 2009). It should be noted, however, that since the themes of laws, issues, and efforts were identified ahead based on the conceptual interest of this research, the process of analysis was performed in a deductive manner (Braun \& Clarke, 2006).

This document analysis technique was applied in this study at various stages. The researcher initially familiarized himself with the gathered data in each document, providing attention to relevant codes that occur and noting down these codes. Then, the researcher grouped the codes according to their relevance to the identified themes or conceptual interest of this research on the laws, issues, and efforts as regards the condition of senior citizens. The researcher carefully appraised the relevance between the codes and conceptual interest of the research, repetitively returning to the original documents for review as needed until the final results were produced.

\section{Results}

The results of this review article focus on its conceptual interest on the enabling laws, current issues, and shared efforts as regards the condition of the senior citizens during the COVID-19 crisis in the Philippines. They are logically discussed as follows.

\section{Enabling Laws}

The Philippines has given full recognition of the significance of the senior citizens in the society. This recognition is evident in the various enacted laws. These laws have served as grounds for various programs, interventions, and activities that seek to preserve the general welfare of the senior citizens.

The rights of senior citizens in the Philippines are principally enshrined in the 1987 Philippine Constitution which provides for the creation of policies that ensure the welfare of its citizens. Specifically, Article XIII, Section 2 provides that "The State shall adopt an integrated and comprehensive approach to health development which 
8 Senior Citizens during COVID-19: Laws, Issues, Efforts

shall endeavor to make essential goods, health and other social services available to all people at an affordable cost. There shall be a priority for the needs of the underprivileged sick, older, disabled, women, and children." Moreover, Article XV, Section 4 states that "It is the duty of the family to take care of its older person members while the State may design a program of social security for them." These provisions are translated into various laws.

One of these laws that serve as the backbone to the rights of senior citizens is the Republic Act No. 7432 which was enacted on July 22, 1991. It is known as "An Act to Maximize Contribution of Senior Citizens to Nation Building, Grant Benefits, and Special Privileges and for Other Purposes." Aside from acknowledging the contributions of older persons in nation-building, it encourages families and communities to rekindle the Filipino tradition of caring for older persons. Among its practical provisions are the grants of the 20 percent discount from all establishments related to transportation, accommodation, food, recreation, and medicine all over the country. It also exempted them from the payment of individual income taxes.

This law was then amended by Republic Act No. 9257 on February 26, 2004. It is known as the "Expanded Senior Citizens Act of 2003". It expanded the coverage of the benefits and privileges to the senior citizens to include all business establishments. It further acknowledges the important role of the private sector in the improvement of the welfare of senior citizens and actively enjoin their cooperation. It provides broad health care and rehabilitation system for senior citizens with disabilities to raise their capability to realize a more productive maturing life.

Another amendment to the said law was later made when Republic Act No. 9994 was approved on February 15, 2010. Known as "Expanded Senior Citizens Act of 2010", it increased the coverage of the entitlements of the senior citizens to include a $20 \%$ discount and exemption from the value-added tax on certain goods and medical services. Added items also are discounts for funeral services, burial services, water bills, and electric bills. This law also augmented daily 
subsistence and other medical needs of senior citizens by providing monthly social pension amounting to 500 pesos to indigent senior citizens.

Moreover, a recent amendment this time to cover the senior citizens in the national health insurance program was realized through the Republic Act No. 10645 approved on November 05, 2014. Under also this law, funds necessary to ensure the enrollment of all senior citizens not currently covered by any existing category shall be sourced from the appropriate national fund from proceeds under the pertinent laws and regulations.

An earlier enabling law that promotes for the welfare of senior citizens in the Philippines is the Republic Act No. 7876 enacted on July 25, 1994 and known to be "An Act Establishing a Senior Citizens Center in All Cities and Municipalities of the Philippines". As one of the responses to the constitution, it mandated the establishment of a senior citizens center in all cities and municipalities under the direct leadership of the Department of Social Welfare and Development (DSWD) in cooperation with the local government units. This law aimed to address the socialization needs of senior citizens. The law further stipulates the provision of social and recreational services, health and personal care services, spiritual services, livelihood services, and volunteer resource services for senior citizens.

A comprehensive law was also enacted through the Republic Act No. 8425 on December 10, 1997, known as "An Act Institutionalizing the Social Reform and Poverty Alleviation Program, Crafting for the Purpose the National Anti-Poverty Commission, Defining Its Powers and Functions". Though not specifically for senior citizens, this law recognizes them as a sector represented in the implementation of this law. It put forward a social reform that addresses the fight against poverty through an approach involving various sectors and recognizing the core values, cultural integrity, and spiritual diversity of the target communities.

Furthermore, budgetary concern for those programs intended for senior citizens is addressed by the Republic Act No. 9336 known as 
10 Senior Citizens during COVID-19: Laws, Issues, Efforts

The General Appropriations Act 2006. Particularly under Section XXXII, it mandates one percent allocation of agency budget to programs and services for older persons and persons with disabilities. It ordered that all government units allot one percent of their total financial plan to programs and activities for the senior citizens as well as persons with disabilities.

The most recent and timely law enacted as regards the senior citizens and protecting their welfare in times of COVID-19 crisis is the Republic Act No. 11469 or the "Bayanihan to Heal as One Act". which pursues to address the risks and impact of COVID-19 in the country. This act specifically impelled the DSWD to distribute social amelioration cards in preparation for the distribution of cash assistance in light of the COVID-19 pandemic. Cash assistance between 5,000 and 8,000 pesos is specified to vulnerable sectors of society which included the senior citizens.

There are also past presidential proclamations that strengthen these laws on the rights of senior citizens. One is the Executive Order No. 266, series of 2000 that approved and adopted the Philippine Plan of Action for Older Persons. It was issued on July 17, 2000, serving as the blueprint that institutes appropriate policies, strategies, programs, and projects for senior citizens. It also created the committee on senior citizens involving several agencies that shall be accountable for coordinating, monitoring, and evaluating the plan.

Another is Executive Order No. 105, which approved and directed the program provides for detached and poor older persons among others, issued in 2002. Its main feature is the housing program that will address the housing requirements of neglected, abandoned, abused, and unattached older persons and promote the contextualized program for older persons. This law was also encouraged businesses to align their corporate social responsibility towards providing the essential infrastructure for deprived senior citizens.

The reviewed laws have focused on securing the integral needs of the senior citizens as far as physical, psychological, economic, and social aspects are concerned. It can also be noted that there is a desire 
for a multi-dimensional and cross-sectoral approach in translating these laws into effective programs, interventions, and activities.

\section{Current Issues}

The Philippine government has been relatively successful in doing initiatives for the implementation of laws that look after the welfare of senior citizens. However, with the current COVID-19 crisis, there resurfaced unspoken issues that led to exacerbation of the conditions of vulnerable groups of the society including the aged group.

Many working senior citizens, especially those from the poor segment, were estimated to have been deprived of their income because of the COVID-19. A result from the 2018 Longitudinal Study of Ageing and Health in the Philippines showed that 46 percent of the senior citizen population lives below the poverty line. The gender lens further disclosed that 57 percent of the men work as compared to 39 percent of the women within this aged group. Moreover, while 42 percent of the senior citizens have a pension, only half declared pension as their most essential income source with comparable levels for both men and women (Cruz et al., 2018). When translating these data to the current situation, it is evident that especially the very poor and women senior citizens would most likely be affected.

Furthermore, there were also issues of senior citizens suffering from a scarcity of food and medicine as they lingered indoors during the COVID-19 quarantine. While the crisis administrators develop policies to address the basic needs of senior citizens, a substantial number of this vulnerable group has been barely surviving in circumstances made more unendurable by the quarantine (Binay, 2020). This condition is reflected in the words of a senior citizen who expressed in a media interview that since the quarantine, the government has offered not enough assistance. She mentioned needs such as medicines and face masks which she cannot afford. There were also instances when quarantine guidelines are unclear and caused 


\section{Senior Citizens during COVID-19: Laws, Issues, Efforts}

confusion, making access to food and other basic commodities even more difficult (Paul, 2020).

This challenging situation of senior citizens during the COVID-19 crisis is compounded by the inadequacy of living space for physical distancing. Perez (2020) of the Commission on Population and Development analyzed the living space Filipinos have and whether physical distancing is possible. Basing on the statistics, it was found out that a significant number of senior citizens are residents in cramped houses. Hence, senior citizens may be put at a greater risk of getting infected with COVID-19 given this population density. On the other hand, another significant number of senior citizens live alone in this housing type, apart from any family member. Thus, they may suffer from psychosocial pressures.

Another issue that emerged amid the crisis is the government announcement that senior citizens would be prohibited to leave their homes even after enhanced community quarantine measures were lifted. Many criticisms from heated senior citizens have made the government take back its earlier pronouncement. A noise followed tagging the plan as an "a blacklist" and "house arrest". Others cited statistics that ostensibly show that the age brackets make up only the minority of the COVID-19 cases in the country. They believe that restricting senior citizens is baseless and disregarding their civil liberties (Gascon, 2020; Lina, 2020; Paul, 2020; Robles, 2020).

This issue must also be a result of the long spoken perceptions of senior citizens in the country. With the previous propensity of the government towards barring the senior citizens from leaving their homes during the easing of COVID-19 quarantine measures, Quitoriano (2020) argued that rules feign that being a senior citizen is equal to weak for COVID-19. Arranza (2020) also found it prejudiced, if not discriminatory, to distinguish all senior citizens as helpless against the COVID-19 because of their age, describing such continued restriction as torture for them.

Overall, the current crisis has served as a challenge, but which has overtly exposed several issues of existing inequalities that drive senior 
citizens further into new levels of vulnerabilities. These issues affecting the senior citizens are found to exacerbate mainly their income sources, access to essential needs, physical space, and social perceptions towards them.

\section{Shared Efforts}

Many individuals and institutions have expressed support for the improvement of the conditions of the senior citizens in the Philippines and especially during this time. Their shared efforts offer insights as to ways with which how the laws can be effectively implemented and issues be immediately resolved amid the COVID-19 crisis.

The curb on the mobility especially of senior citizens primarily served to drive them towards grave financial difficulties in the last four months. As an expression of concern, the University of the Philippines Population Institute and the Demographic Research and Development Foundation (2020) has called for attention to this issue experienced by the senior citizens. They noted based on their analysis that senior citizens are already financially vulnerable under normal circumstances and their conditions are projected to be exacerbated to a greater degree during the current crisis.

Hence, as a way to also address such concern, many analysts saw the need for increased and efficient social pension payout, especially for those impoverished senior citizens. Ducanes et al. (2020) suggested that the needed increased funding for social pension payout can be sourced from the disaster or calamity funds of the local governments, as there is a provision in the laws. On the other hand, they also added that the senior citizens offices, which are entrenched in the different levels of the political units all over the country, should be mobilized for the efficient release of the social pension.

Several individuals, including lawmakers, have likewise called for the careful review of the guidelines to give senior citizens the safe mobility. The senior citizens come from heterogeneous populations, thus needing different guidelines. For example, the senior citizens and 
other household members who will seek medical services as well as buy food should be allowed (Barcelo, 2020). Especially for senior citizens who are still functional in their jobs, they should also be permitted to leave homes to perform their business (Arranza, 2020). On the other hand, those living alone may need to strengthen their physical and mental health by walking around the park and other related exercises (Quitoriano, 2020).

There is also a need to innovate approaches in essential activities. Especially for senior citizens who are not used to online gadgets or in places with a poor internet connection, adoption of a "mobile market" model should be considered. The government unit of Pasig, a city in the Philippines, has developed an innovative approach to help its residents purchase food during the quarantine. Rather than go with the crowd in the markets to buy essential needs, the residents just had to wait for the "mobile market" that went around homes in the different areas (Casinas, 2020; Kabagani, 2020).

As with senior citizens who have a substantial support system to use online gadgets and are in places with a stable internet connection, the use of online stores and delivery is highly encouraged. Several grocery delivery services in big cities can be easily accessed online or even through phone applications (Adalid, 2020). Online drugstore can also be accessed especially for senior citizens. It can be done through the website of various pharmacies and also mobile applications (Zoleta, 2020).

These approaches may be developed in other cities and towns to cater to the essential needs of the senior citizens. The cooperation of local government units and the business sectors is highly needed in this endeavor. A senator has also suggested other options like the implementation of "special hours" and priority services at groceries and pharmacies for the senior citizens who need to physically go out (Abad, 2020).

Furthermore, telehealth is seen to be the key to bridging the space between senior citizens and medical service providers. Apart from giving people who reside in remote areas access to basic health care 
services, telehealth will also create the foundation for digital medical records. The combined effort of the University of the Philippines, Department of Health, Department of Information, Communication and Technology, and Food and Drugs Administration is highly sought to achieve this vision (Angara, 2020).

Lastly, to realize most of the recommendations above, the government should partner with telecommunication companies to meet the demand for internet data and sustain the connections. While the enhancement of internet connectivity is a concern, the provision of a meaningful one is another. To become meaningful, such effort must consider the contexts of vulnerable groups including the senior citizens and others. It must assure that all users can fully utilize connectivity and protect themselves from risks, such as online frauds and abuses (Bueno \& Pacis, 2020).

Shared efforts from various individuals and groups are being placed to help the senior citizens transition to a new period. These efforts have called for the improvement of social pension payout, guidelines for mobility, different approaches of remote access to essential goods and services, and meaningful internet connectivity.

\section{Conclusion}

This research was guided by its aim to discuss the condition of senior citizens in the Philippines during the COVID-19 crisis. It provides evidence as regards the enabling laws, current issues, and shared efforts related to the context. It serves as a significant knowledge input so that comprehensive, relevant, and appropriate mechanisms can be formulated to eventually improve the conditions of the senior citizens not only on the current crisis but also in the long run.

This review revealed that the Philippines, within the current context of COVID-19 crisis, has a history of various enabling laws through its constitution, republic acts, and executive orders that have been enacted to secure the overall welfare of the senior citizens. These laws consider especially those senior citizens below the poverty line 
and from impoverished areas through multi-dimensional and crosssectoral strategies.

Béland and Marier (2020) similarly discussed extant policy legacies and the new policy opportunities in the context of the current COVID-19 pandemic in Canada. They concluded that the crisis has served as an opener for a genuine "policy window" that may facilitate broad reforms, especially bolstering policy funds for older people, amid the global crisis. On the other hand, Lum et al. (2020) drew their discussion of the current policies for older people in Hong Kong from the experiences of the region during a previous epidemic. The authors reviewed the government responses to the current situation with particular attention on the ways the policies contained the spread of the virus into residential care facilities, thus protect older people from high possibilities of health risks.

Moreover, it was found out in this paper that the current COVID19 crisis has magnified issues that worsen many existing forms of inequalities that drive senior citizens further into new vulnerabilities. These issues affecting the senior citizens revolve around the deprivation of income sources, inaccessibility to essential needs, inadequate physical space, and spoken negative perceptions, which all reflect ageism at different levels.

Such ingrained ageism issues reflect the global experience of older people in the wake of the COVID-19 pandemic. For example, De Leo and Trabucchi (2020) reported the peculiar reactions to isolation, loneliness, and fear exhibited by older people during the crisis. Meng et al. (2020) further presented empirical evidences that show some significant percentages of older people experiencing depression because of the current situation. Drawing from social connectedness as a risk factor, Liotta et al. (2020) also revealed that the virus contagion was more severe in regions with higher family disintegration, a situation which happens for many older people, while Banerjee (2020) stressed the elderly mental vulnerabilities in the context of the global crisis and ageism. On the other hand, Deusdad (2020), who disclosed scarcity of resources for older people in care 
institutions, advocated for a contemplation on the practices that replicate ageism.

Lastly, this article highlighted the shared efforts from various individuals and groups to assist the senior citizens to go through the transition process to the post-COVID-19 new normal. It was suggestive in the review that a focus should be placed on the improvement of social pension payout, guidelines for mobility, different approaches of remote access to essential goods and services, and meaningful internet connectivity.

Shared efforts to help older people during the COVID-19 outbreak are also being highlighted in other parts of the world. Previtali et al. (2020) acknowledged the various sectors in providing support such as performing simple errands for older people and establishing psychological support for them through help lines. Moreover, Angel and Mudrazija (2020) underscored the role of the government and private institutions should older people get sick or lose their income sources during the pandemic. Morrow-Howell et al. (2020) likewise articulated the various efforts such as "increased comfort with technology and online platforms; stronger family and intergenerational connections, renewed energy to combat social isolation" (p. 527) among others. Hoffmann et al. (2020) also evaluated opportunities that have emerged for enhancing services for older people during the pandemic through efforts such as progressive adoption of telehealth and social interaction, and realization of intergenerational service.

Considering the conclusions drawn for this paper, three suggestion points are offered. There is a need to strengthen the existing Philippine laws for senior citizens through the initiation of programs that address the needs especially of the segment of old women, with existing medical conditions, and in abused and abandoned status. The current ageism issues should also be carefully tackled with sensitivity in the current and future programs to reduce the deleterious impacts of the crisis on the senior citizens. As regards the ongoing shared efforts, 
18 Senior Citizens during COVID-19: Laws, Issues, Efforts

some evidence of good practices in other countries may be contextually considered to sustain or further strengthen such efforts.

\section{References}

Abad, M. (2020, April 28). CHR urges gov't to reconsider restriction of elderly going out. Rappler. Retrieved from https://www.rappler.com/nation/259303-chr-urges-governmentreconsider-restriction-elderly-going-out-coronavirus-pandemic

Adalid, A. (2020, March 28). Top online grocery delivery sites \& apps. I am Aileen. Retrieved from https://iamaileen.com/topbest-online-grocery-delivery-site-app-metro-manila-philippines/ Angel, J. L., \& Mudrazija, S. (2020). Local government efforts to mitigate the novel coronavirus pandemic among older adults. Journal of Aging \& Social Policy, 32(4-5), 439-449. https://doi.org/10.1080/08959420.2020.1771240

Angara, S. (2020, April 08). Angara sees greater need for telemedicine now with the COVID-19 experience. Alagang Angara. Retrieved from http://web.alagangangara.com/wed04082020-1200-angara-sees-greater-need-telemedicine-nowcovid-19-experience

An Act Establishing a Senior Citizens Center in All Cities and Municipalities of the Philippines, Republic Act No. 7876. (1994). Retrieved from https://www.officialgazette.gov.ph/1995/02/14/republic-act-no$7876 /$

An Act Institutionalizing the Social Reform and Poverty Alleviation Program, Crafting for the Purpose the National Anti-Poverty Commission, Defining Its Powers and Functions, Republic Act No. 8425 (1997). Retrieved from https://pcw.gov.ph/law/republic-act-8425

An Act Providing for the Mandatory Philhealth Coverage for All Senior Citizens, Republic Act No. 10645 (2014). Retrieved from 
https://www.officialgazette.gov.ph/2014/11/05/republic-act-no$10645 /$

An Act to Maximize Contribution of Senior Citizens to Nation

Building, Grant Benefits and Special Privileges and for Other

Purposes, Republic Act No. 7432 (1991). Retrieved from

https://www.pcw.gov.ph/law/republic-act-7432

Approving and Adopting the Philippine Plan of Action for Older

Persons, Executive Order No. 266 (2000). Retrieved from

https://www.officialgazette.gov.ph/2000/07/17/executive-orderno-266-s-2000/

Approving and Directing the Implementation of the Program

"Provision of Group Home/Foster Home for Neglected,

Abandoned, Abused, Detached and Poor Older Persons and

Persons with Disabilities”, Executive Order No. 105 (2002).

Retrieved from

https://www.officialgazette.gov.ph/2002/05/16/executive-orderno-105-s-2002/

Arranza, J. L. (2020, May 20). The wisdom of the elderly amid Covid19. Business Mirror. Retrieved from

https://businessmirror.com.ph/2020/05/20/the-wisdom-of-theelderly-amid-covid-19/

Banerjee, D. (2020). 'Age and ageism in COVID-19': Elderly mental health-care vulnerabilities and needs. Asian Journal of Psychiatry, 51, 102154.

https://doi.org/10.1016/j.ajp.2020.102154

Barcelo, V., Ramos-Araneta, M., Cruz, M. V., \& Campos, O. V. (2020, May 01). 'New normal' sets in under GCQ - Palace.

Manila Standard. Retrieved from

https://manilastandard.net/mobile/article/322774

Bayanihan to Heal as One Act, Republic Act No. 11469 (2020).

Retrieved from

https://www.officialgazette.gov.ph/2020/04/01/implementingrules-and-regulations-of-section-4aa-of-republic-act-no-11469otherwise-known-as-the-bayanihan-to-heal-as-one-act/ 
20 Senior Citizens during COVID-19: Laws, Issues, Efforts

Béland, D., \& Marier, P. (2020). COVID-19 and long-term care policy for older people in Canada. Journal of Aging \& Social Policy, 32(4-5), 358-364.

https://doi.org/10.1080/08959420.2020.1764319

Binay, J. C. (2020, May 12). Senior citizens under lockdown. Manila Bulletin. Retrieved from

https://news.mb.com.ph/2020/05/06/senior-citizens-underlockdown/

Bowen, G. A. (2009) Document Analysis as a Qualitative Research Method. Qualitative Research Journal, 9(2), 27-40. https://doi.org/10.3316/qrj0902027

Braun, V., \& Clarke, V. (2006). Using thematic analysis in psychology. Qualitative Research in Psychology, 3(2), 77-101. https://doi.org/10.1191/1478088706qp063oa

Bueno, A. \& Pacis, J. (2020, May 20). As COVID-19 forces life to move online, who is left behind? CNN Philippines. Retrieved from https://cnnphilippines.com/life/culture/2020/5/20/internetaccess-pandemic.html

Casinas, J.A. (2020, March 24). Vico Sotto launches 'mobile palengke' in Pasig City to encourage residents to stay indoors. Manila Bulletin. Retrieved from

https://news.mb.com.ph/2020/03/24/vico-sotto-launchesmobile-palengke-in-pasig-city-to-encourage-residents-to-stayindoors/

Chang, E.-S., Kannoth, S., Levy, S., Wang, S.-Y., Lee, J. E., \& Levy, B. R. (2020). Global reach of ageism on older persons' health: A systematic review. PLOS ONE, 15(1), e0220857.

https://doi.org/10.1371/journal.pone.0220857

Cruz, G. T. (2019). Are Filipino older people enjoying longer healthy years? Philippine Population Association Scientific Conference. Retrieved from https://www.un.org/

Cruz, G. T., Cruz, C. J. P., \& Saito, Y. (2018). Longitudinal study of ageing and health in the Philippines. Jakarta, Indonesia: Economic Research Institute for ASEAN and East Asia. 
Desk research [Def.2]. (2020). In Cambridge Business English

Dictionary. Retrieved June 25, 2020 from

https://dictionary.cambridge.org/us/dictionary/english/deskresearch

Deusdad, B. (2020). COVID-19 and nursing homes' crisis in Spain:

Ageism and scarcity of resources. Research on Ageing and

Social Policy, 8(2), 142-168.

http://dx.doi.org/10.447/rasp.2020.5598

De Leo, D., \& Trabucchi, M. (2020). COVID-19 and the fears of Italian senior citizens. International Journal of Environmental Research and Public Health, 17(10), 3572.

https://doi.org/10.3390/ijerph17103572

Ducanes, G. M., Daway-Ducanes, S. L. S., \& Ravago, M. L. V. (2020). Special programs needed for the elderly and elderly households during the enhanced community quarantine. [Policy brief]. Ateneo de Manila University. Retrieved from http://www.ateneo.edu/ls/soss/economics/downloads/pb-202002-special-programs-needed-elderly-and-elderly-householdsduring

Expanded Senior Citizens Act of 2003, Republic Act No. 9257 (2003). Retrieved from

https://www.officialgazette.gov.ph/2004/02/06/republic-act-no$9257 /$

Expanded Senior Citizens Act of 2010, Republic Act No. 9994 (2010). Retrieved from

https://www.officialgazette.gov.ph/2010/02/15/republic-act-no9994/

Fabon III, E. (2020, July 30). Growing old and poor in the Philippines. One News. Retrieved from https://onenews.ph/growing-old-andpoor-in-the-philippines

Frey, B. (2018). The SAGE encyclopedia of educational research, measurement, and evaluation. Thousand Oaks, CA: SAGE Publications, Inc. https://doi.org/10.4135/9781506326139 
22 Senior Citizens during COVID-19: Laws, Issues, Efforts

Gascon, M. (2020, April 30). Quarantine restrictions based on age slammed. The Nation Thailand. Retrieved from https://www.nationthailand.com/news/30387048?utm_source=c ategory\&utm_medium=internal_referral

Ghilarducci, T., \& Farmand, A. (2020) Older workers on the COVID19- frontlines without paid sick leave. Journal of Aging \& Social Policy, 32(4-5), 471-476.

https://doi.org/10.1080/08959420.2020.1765685

Guptill, A. (2016). Secondary sources in their natural habitats. Writing in College. Retrieved from

https://milnepublishing.geneseo.edu/writing-in-college-fromcompetence-to-excellence/chapter/secondary-sources-in-theirnatural-habitats/

Hoffman, G. J., Webster, N. J., \& Bynum, J. P. W. (2020). A framework for aging-friendly services and supports in the age of COVID-19. Journal of Aging \& Social Policy, 32(4-5), 450-459. https://doi.org/10.1080/08959420.2020.1771239

Kabagni, L.J. (2020, March 25). Pasig City's 'mobile palengke' boosts social distancing. Philippine News Agency. Retrieved from https://www.pna.gov.ph/articles/1097797

Lai, C.-C., Shih, T.-P., Ko, W.-C., Tang, H.-J., \& Hsueh, P.-R. (2020). Severe acute respiratory syndrome coronavirus 2 (SARS-CoV2) and coronavirus disease-2019 (COVID-19): The epidemic and the challenges. International Journal of Antimicrobial Agents, 55(3), 105924.

https://doi.org/10.1016/j.ijantimicag.2020.105924

Lina, J. (2020, May 12). Not all seniors and youngsters ought to be restricted. Manila Bulletin. Retrieved from https://news.mb.com.ph/2020/05/05/not-all-seniors-andyoungsters-ought-to-be-restricted/

Liotta, G., Marazzi, M. C., Orlando, S., \& Palombi, L. (2020). Is social connectedness a risk factor for the spreading of COVID19 among older adults? The Italian paradox. PLOS ONE, 15(5), e0233329. https://doi.org/10.1371/journal.pone.0233329 
Lum, T., Shi, C., Wong, G., \& Wong, K. (2020) COVID-19 and longterm care policy for older people in Hong Kong. Journal of Aging \& Social Policy, 32(4-5), 373-379.

https://doi.org/10.1080/08959420.2020.1773192

Meng, H., Xu, Y., Dai, J., Zhang, Y., Liu, B., \& Yang, H. (2020). Analyze the psychological impact of COVID-19 among the elderly population in China and make corresponding suggestions. Psychiatry Research, 289, 112983. https://doi.org/10.1016/j.psychres.2020.112983

Morrow-Howell, N., Galucia, N., \& Swinford, E. (2020). Recovering from the COVID-19 pandemic: A focus on older adults. Journal of Aging \& Social Policy, 32(4-5), 526-535.

https://doi.org/10.1080/08959420.2020.1759758

Paul, S. (2020, June 05). Philippines' senior citizens vulnerabilities increase because of COVID-19 lockdown. Inter Press Service. Retrieved from

http://www.ipsnews.net/2020/06/philippines_senior_citizens_vu lnerabilities_increase/

Perez III, J. A. (2020, April 19). Bringing the COVID-19 fight to where it lives. Commission on Population and Development. Retrieved from http://popcom.gov.ph/bringing-the-covid-19fight-to-where-it-lives/

Previtali, F., Allen, L. D., \& Varlamova, M. (2020) Not only virus spread: The diffusion of ageism during the outbreak of COVID19. Journal of Aging \& Social Policy, 32(4-5), 506-514, https://doi.org/10.1080/08959420.2020.1772002

Quitoriano, E. (2020, April 17). Struggles of a senior citizen in the time of COVID-19. Minda News. Retrieved from https://www.mindanews.com/mindaviews/2020/04/reflectionsstruggles-of-a-senior-citizen-in-the-time-of-covid-19/

Reynolds, L. (2020). The COVID-19 pandemic exposes limited understanding of ageism. Journal of Aging \& Social Policy, 32(4-5), 499-505.

https://doi.org/10.1080/08959420.2020.1772003 
24 Senior Citizens during COVID-19: Laws, Issues, Efforts

Robles, A. (2020, May 01). Coronavirus: elderly backlash forces Philippines to rethink quarantine exit plan. The South China Morning Post. Retrieved from https://www.scmp.com/weekasia/politics/article/3082369/coronavirus-elderly-backlashforces-philippines-rethink

Sileyew, K. J. (2019). Research design and methodology. In E. AbuTaieh, A. El Mouatasim, \& I. H. Al Hadid (eds.), Cyberspace. London: IntechOpen. https://doi.org/10.5772/intechopen.78887 The General Appropriations Act of 2006, Republic Act No. 9336 (2006). Retrieved from

https://www.officialgazette.gov.ph/2005/03/15/republic-act-no9336/

United Nations (2020). The impact of COVID-19 on older persons

[Policy brief]. Author. Retrieved from

https://unsdg.un.org/sites/default/files/2020-05/Policy-Brief-

The-Impact-of-COVID-19-on-Older-Persons.pdf

University of the Philippines Population Institute and the

Demographic Research and Development Foundation (2020).

COVID-19 and the economic vulnerability of older Filipinos

[Policy brief]. Authors. Retrieved from

https://www.uppi.upd.edu.ph/sites/default/files/pdf/COVID-19-

Research-Brief-02.pdf

World Health Organization (2020). Older people are at highest risk

from COVID-19, but all must act to prevent community spread.

Retrieved from https://www.euro.who.int/en/health-

topics/health-emergencies/coronavirus-covid-

19/statements/statement-older-people-are-at-highest-risk-fromcovid-19,-but-all-must-act-to-prevent-community-spread

Xie, B., Charness, N., Fingerman, K., Kaye, J., Kim, M. T., \&

Khurshid, A. (2020). When going digital becomes a necessity:

Ensuring older adults' needs for information, services, and social inclusion during COVID-19. Journal of Aging \& Social Policy, 32(4-5), 460-470.

https://doi.org/10.1080/08959420.2020.1771237 
RASP - Research on Ageing and Social Policy, 9(1) 25

Zoleta, V. (2020, April 06). 9 Online Drugstores in the Philippines for Medicine Delivery and Pickup. Moneymax. Retrieved from https://www.moneymax.ph/lifestyle/articles/online-drugstoresphilippines

Michael Cahapay. Assistant Professor at College of Education,

Contact Address: Mindanao State University, Fatima, General Santos City, 9500 South Cotabato, Philippines. mbcahapay@up.edu.ph 